\title{
Democratization of the United Nations: What is Expected of India and the European Union?
}

\author{
Avijeet Kumar Biswas, B. Krishnamurthy
}

\begin{abstract}
The United Nations Security Council reflects a setup of the past rather than the reality of the present world order. There has been a clamour for the induction of new countries as permanent members into the council to render it truly universal. But would the expansion of the permanent members naturally lead to the democratization of the most important international organization?India has been one of the claimants for permanent membership. Even though India's demand is legitimate, it must first seek and secure its place at the global high table and should play a role in helping shape the global order.The European Union tries to lead and influence the international politics by its example and intends to replicate its success at the global level. Just like India, the $E U$ is a votary of 'multilateralism' and it stands for the UN, and insists on the need for international laws, agreements, rules and institutions. India is part of EU's global security strategy and is considered as one among the 'key' strategic partners. $E U$ can thus be the perfect and reliable partner for India to achieve its foreign and strategic policy goals. India should join hands with the EU to formulate new global democratic laws and norms, thereby becoming a norm setter on its own right.
\end{abstract}

Keywords: Democratization, European Union, India, United Nation.

\section{INTRODUCTION}

Democratization of the United Nations (UN) is projected as an important issue by all concerned and it is claimed rightly that the international organization, to be truly international and legitimate, should inevitably reflect the trends of the contemporary global politics. There is a clarion call that the Global South, which had been kept out of the international political and financial power centres and decision making tables, needs to be duly represented in these bodies. Claimants of the United Nations Security Council (UNSC) permanent membership like India place their claim on the desirability of democratization of the international organization and argue that the present set up which might have reflected the geopolitical realities of the mid-twentieth century is no more suitable to the second decade of the twenty first century. It is rightly claimed that the UN and especially, the UNSC is reflecting those of 1945 rather than that of 2019. In 1945, the UNSC consisted of eleven members, with the total UN membership of fifty one - about 22 per cent. In 2014, the UNSC consisted of fifteen members while the member countries have increased to more than 190 - fewer than 8 per cent. Advocates of the enhancement of the UNSC permanent seats argue that Asia,

Revised Manuscript Received on July 22, 2019

Avijeet Kumar Biswas, Centre for European Studies, Pondicherry University, Pondicherry, India. Email: avijeet89.res@ pondiuni.edu.in

Prof. (Retd.) B. Krishnamurthy, Centre for European Studies, Pondicherry, India. Email: bkris53@gmail.com the most populated continent, is under-represented with China as the only member and Europe, which accounts for barely 5 per cent of the world's population, still controls 33 per cent of the seats in any given year and thus, is unduly over-represented. Ironically, Germany and Japan, who contribute financially to the UN budget at 12 per cent and 19 per cent respectively, are still out of the UN power structure [1]. While the present permanent members of the UNSC are wary and/or indifferent on the issue, the advocates and probable beneficiaries of the process, however, consider democratization of the $\mathrm{UN}$ as the question of the inevitable enhancement of the permanent members of the UNSC with veto power.

In this regard, the present paper argues the case of India for a UNSC permanent membership. While taking the size of the country and of its population, historical legacy, democratic polity and emerging economic potentials, the Indian claim is but natural and understandable, even if not, indisputable. Again, it puts forth the argument that India and the European Union (EU), who stand for multilateralism in the international politics through the activisation of the UN, should reinforce each other and work in unison to revitalise it so as to make it viable and successful [2]. While pinpointing that enhancement of the number of permanent members alone will not be enough to achieve democratization, the present work maintains that India should assume its international responsibilities with earnestness and actively play its due role in the democratization of the decision-making processes of the UN and also strengthen its hands in protecting the 'global Commons' through the formulation and strict implementation of the 'global public goods'.

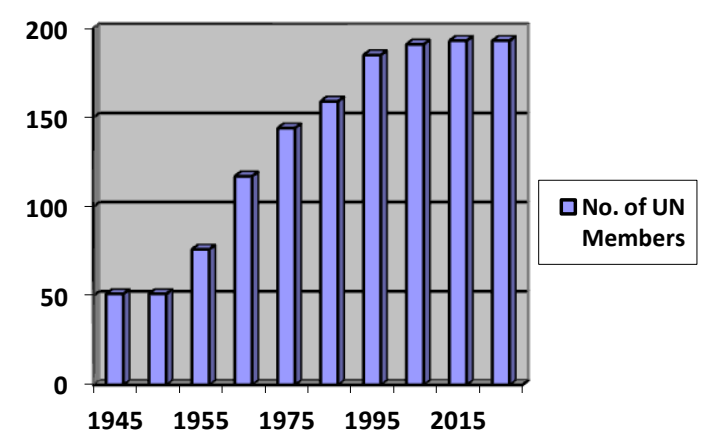

Fig. 1. Historical Record of UN Membership (Source: United Nations)

\section{THE CLAMOUR FOR EXPANSION}

Since Asia remains underrepresented and Africa and Latin America are completely 
left out of the UNSC, a call for proper regional representation is put forth by the likely beneficiaries of UNSC permanent seat enhancement. In the post-cold war era, the demand assumed a new vigour. The Group of Four - India, Germany, Japan and Brazil - countries are supporting each other's claims and are individually and collectively trying to secure the backing of the present permanent members and other member countries of the UN General Assembly.

Ironically, against their claim there are counter claims. On the claim of Germany, Italy has put forth its counter claim. China and South Korea are against Japan for historical reasons. Pakistan challenges Indian claim due to rivalry of the siblings [3]. Argentina and Mexico are against Brazil on the ground that how Portuguese Brazil can represent largely Hispanic Latin America. There is a neck to neck competition among Nigeria, the largest democracy, South Africa, the largest economy and Egypt, the birth place of one of the ancient civilizations on who is to represent Africa. Besides, the African Union, under the label of 'the Ezulweni Consensus', puts forth its almost unachievable demand for two veto-wielding permanent seats for Africa, most probably with the idea of keeping the whole issue in animated suspension, on its own or at the behest of the statusquoists.

\begin{tabular}{|c|c|}
\hline \multicolumn{2}{|c|}{ Security Council Members as of 2019} \\
\hline Country & Term ends \\
\hline China & Permanent Member \\
\hline Belgium & 2020 \\
\hline Côte d'Ivoire & 2019 \\
\hline Dominican Republic & 2020 \\
\hline Equatorial Guinea & 2019 \\
\hline France & Permanent Member \\
\hline Germany & 2020 \\
\hline Indonesia & 2020 \\
\hline Kuwait & 2019 \\
\hline Peru & 2019 \\
\hline Poland & 2019 \\
\hline Russian Federation & Permanent Member \\
\hline South Africa & 2020 \\
\hline United Kingdom & Permanent Member \\
\hline United States & Permanent Member \\
\hline
\end{tabular}

Table 1. UNSC Membership as of July 2019.

On the face of claims and counter claims, certain viamedia solutions and suggestions are also in the offing. On the realization that adequate support is not forthcoming from all concerned, P-4 countries are even offered to accept UNSC permanent membership without veto power. Another such formula was the claimants and the counter claimants, as a compromise measure, will enjoy two and a half tenure for each, thereby a new category of semi-permanent membership shall be introduced in the UNSC. Some aspiring countries are even ready to givean assurance that they will not use veto for the first fifteen years, in case of given permanent membership with veto power.

Any sensible observer of the UNSC structure and functioning will accept that what looks anomalous at present with just five permanent members with veto power will seem absurd too soon. Legitimacy of the UNSC is expected to be challenged and disputed. Questions on the under representations of Asia, Africa and Latin America on the one hand and on the over representation of Europe, which needs to be corrected, will inevitably arise. Though, as of now, there is no call for replacing the existing European permanent members, in near future there is every chance of them facing such a clamour. Getting them replaced with one permanent seat for EU will mount and may prove irresistible.

In this regard, the Europeans should realize that the EU as a collectivity alone can be a pole in the ensuing the multipolar world and no European country, either France or Germany or the UK, is capable enough to play that role on its own stature and prowess. As such, the present permanent members of the UNSC, France and the UK, have to make the 'supreme sacrifice' of voluntarily relinquishing their seats (by way of owning moral responsibility for their acts of omission and commission at the UNSC so far), in favour of the European Union and Germany should not insist on its claim. This will prove to be the ultimate litmus test for the European claim that they have voluntarily surrendered so as to pool their sovereignty for the common good of the Europe and of the world.

Under the framework of the European Common Foreign and Security Policy, this issue was dealt with surreptitiously. Specifically regarding the UNSC, the Treaty of the European Union (TEU) provides that, when the Union has defined a position on a subject which is on the UNSC's agenda, the Member States that sit in the UNSC shall request the High Representative (HR) of the Foreign and Security Policy to be invited to present the Union's position (Article 34(2) TEU). This provision does not clarify when a position has been defined, e.g. in the case of a formal Council decision, or more generally Council conclusions or a declaration by the HR on behalf of the EU. Nonetheless, it allows the EU to become a more visible actor at the UNSC. It was put into practice for the first time on May 4, 2010, when HR Ashton held her first speech at the UNSC on the subject of cooperation between the United Nations and regional and sub-regional organizations in maintaining international peace and security. The participation of the HR - and, in practice, of the head of the Union delegation at the UN in New York - is, from the UN side, founded on Rule 39 of the provisional rules of procedure of the UNSC, which still, remains a weak basis. The facts that other EU Member States sitting in the UNSC also took the floor, just after the $\mathrm{HR}$, mostly repeating what the HR had said, demonstrates that Member States are not willing to give up their national voice, even after an EU stance is reached and Article 34(2) TEU does notprovide for coordination between all Member States, but only for concertation between those sitting on the UNSC and for full information vis-à-vis the others, remain a serious handicap for EU 'actorness' in the UNSC [4]. 


\section{IS ENLARGEMENTTHE SOLUTION?}

However, it should be realized that the enhancement of the number of permanent membership of the UNSC alone cannot ensure or be all and end all of the democratization process, which will be actually realised only if there is scope for taking decisions in a democratic way. So far, the present five permanent members of the UNSC have failed the UN and the international community by their misuse and abuse of veto power for taking or stalling decisions, which were far from democratic and were always taken to protect the wrong-doers, who often turned out to be themselves and/or their allies. This 'veto paralyses' always resulted in the inactivisation of the international organisation, which was established for the protection and promotion of world peace, prosperity and human rights. This being the case, democratization of the UN actually means that the real issue is not only countries like India getting UNSC permanent membership with veto power, but also the way in which and issues for which these countries are going to use their veto power and how far it is going to be different from the way in which the present P-5 have used the veto so far. It is hoped that bringing these new countries on the high table will change the nature and content of the debate and the decisions [5].

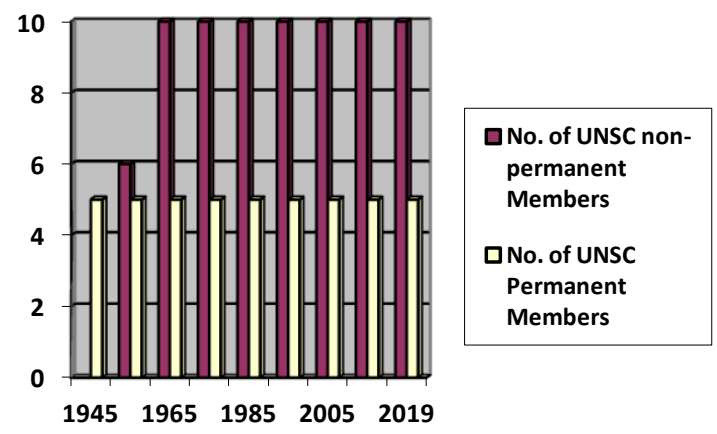

Fig. 2. Historical Record of Non-Permanent and Permanent UNSC Members (Source: United Nations)

Again, there remains an important task of protecting and policing the global commons, the maritime, air, space and cyber space domains that comprise the circulatory system of ourglobalised world and also to the collection of resources and institutions that are part of the often intangible patrimony of humankind. They are concerned with environment, outer space, cyber space, worldwide web, internet, and the waters of the Oceans. They are also related to the unexplored continents like Arctic and Antarctic which may well become both habitable and exploitable as a result of the trends in global warming. Global commons are beyond national jurisdiction of any specific country and needs to be taken care of by international organizations like the UN and its agencies. Global commons hold together the international order based on near-uncontested access, the rule of law and freedom of manoeuvre.

The protection and preservation of clean and green environment, controlling global warming and cutting Carbon emission level, keeping open the sea lanes of communication across international waters, and trade routes and energy supply lanes safe and secure is the need of the hour. Especially, ensuring maritime security from the Horn of Africa to the Straits of Malacca, and finalizing rules governing the exploitation of outer space and proper management of outer space which could increasingly become a new theatre for global competition are of high importance. Protecting cyber space from the depredations of hostile forces including non-governmental ones can be overlooked only at the cost of humanity.

Formulating laws, rules and regulations of the road to guide and control international political and economic order and establishing/setting norms are referred to as global public goods, which were earlier set by the present developed countries. Naturally, there is a feeling among the developing countries, especially the emerging/emerged economic power houses like China and India that these rules and the enforcing mechanism worked in favour of the norm setters and they were always at the receiving ends. As such, there is a dire need for the emerging countries like India to take on this important international responsibility so that the norms may be set and secured for the benefit of all. It is better to be norm setters rather than breakers and getting branded as rebels.

\section{INDIAIN THE WORLD ORDER}

As a matter of policy as well as strategy, India has long staked its international power heavily on multilateral institutions - the Commonwealth, the Non-Aligned Movement, and the United Nations and to a limited extent, the World Trade Organisation (WTO). It is an active participant in the UN System and contributes substantially in kind, through participation in UN peacekeeping operations. In all these institutional platforms India had been and continues to project itself as the leader of the less privileged and systematically exploited developing world. Besides, India has tended to position itself somewhere between the powerful and the powerless, the rich and the poor - and between contending ideological groups and that prompted it to opt for non-alignment as a means for achievement of national independence in foreign policy formulation and relation [6]. It has always donned the mantle of the leader of the developing world in the multilateral political and economic bodies and has voiced for the cause of the 'have nots' of all hues - economic to nuclear.

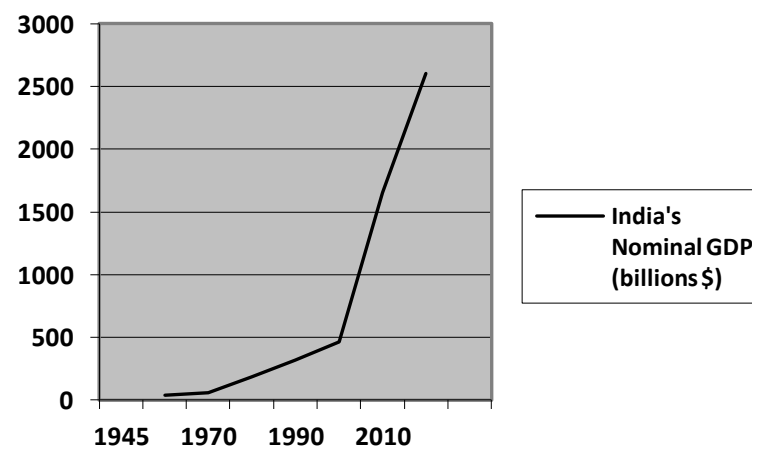

Fig. 3. Growth of India's Nominal GDP from 1960-2017 (Source: World Bank)

As an extension of its non- 
alignment policy, India was worried about the prospect of the UN developing into an instrument of any of the power bloc.David M. Malone, a well-known Canadian diplomat, who attempted at the study of contemporary Indian Foreign Policy, points out that India opposed the 1950 Acheson Plan, also known as the 'Uniting for Peace' resolution, which empowered the UN General Assembly to act on security challenges at times when the UNSC was in deadlock and cites that as its early defence of the veto in the UNSC [7].

In the December 2004 BBC poll 55 per cent of Indians maintained that the UN influence would be mainly positive, while 23 per cent said it would be mainly negative. In the subsequent poll in November 2005, a plurality of Indians, some 44 per cent, said it would be mainly positive, while just 12 per cent said it is mainly negative. Majorities of Indians believe it would be a mainly positive change if the UN becomes significantly more powerful in world affairs. Again, an overwhelming majority of Indians, 88 per cent, favour adding India as a permanent member to the UN Security Council, while just one per cent negativists oppose the Indian claim [8].

However, India's allegiance to multilateralism is not complete. Though India has gained some recognition and benefits through its association with the UN, on several key issues it could not have its way. For instance, Indian experience at the UN in regard to finding a solution to the vexing Kashmir issue has disappointed it thoroughly. India realized belatedly that "the UN Security Council was a political body and that its members take decisions on the basis of their perspective of their national interest and not on the merits of any particular case" [9]. India's grievance is that it is denied of the scope to play its due role in the international politics commensurate with its potentials.

\section{INDIA AS THE NORM SETTER}

Instead of worrying about the UNSC permanent membership and veto power, India should behave like a responsible global powerand should be ready to assume and fulfil its international responsibilities commensurate with its rising power position and its claim to be a major, global power. It should seek and secure its place at the global high table and should play a role in helping shape the global order. It should take initiative to renegotiate the rules of the road and to shape the evolution of the norms as well as to have a voice in the situations within which they are applied. It must contribute its might in the stewardship and preservation of the global commons, which are expected to increasingly become a new theatre for global competition. India must thus contribute on the creation and sustenance of global public goods [10]. India it quite suitable to take lead in this meritorious task since it enjoys enormous legitimacy derived out of the ideological legacies and ideal standards the leadership of its nationalist movement bequeathed to it.

Again, there is a considerate opinion among the scholars of the international relations that the need of the hour is for India to formally articulate a national security strategy in consonance with the overall global environment. It is heartening to note that the first step towards this direction is already been taken by the articulation of the policy paper titled "Nonalignment 2.0: A Foreign and Strategic Policy for India in the Twenty-first Century" authored by a group of leading thinkers, scholars, former diplomats and soldiers, and public figures including Sunil Khilnani, Rajiv Kumar, PratapBhanu Mehta, Lt. Gen. (Retd) Prakash Menon, NandanNilekani, SrinathRaghavan, Shyam Saran and SiddharthVaradarajan, which expectedly provoked an informative national debate and initiated the exercise towards consensus-building in the Indian foreign and strategic policy formulation and execution. Some of their points of view on the objective of non-alignment; the source, nature and redefinition of global, especially India's, power and the genuine goals of Indian foreign policy are worth considering. While maintaining that the nature of global power is undergoing redefinition, Khilnani and others are quite clear that "fundamental source of India's power is going to be the power of its example". According to the authors of the report, the core objectives of Non-Alignment were "to ensure that India did not define its national interest or approach to world politics in terms of ideologies and goals that had been set elsewhere; that India retained maximum strategic autonomy to pursue its own developmental goals; and that India worked to build national power as the foundation for creating a more just and equitable global order". They conclude their report with the following important policy prescriptions along with several others:

1. India must take right steps to assume its rightful place in the world. The first step in this direction and the principal challenge that needs to be met with squarely remains lifting millions of its impoverished citizens out of poverty. India should be determined to redeem this obligation.

2. India must remain true to its aspiration of creating a new and alternative universality.

3. India should be clear about what values its stands for in the international system since its legitimacy will come from its ability to stand for the highest human and universal values, and

4. India should aim not just at being powerful: it should set new standards for what the powerful must do [11].

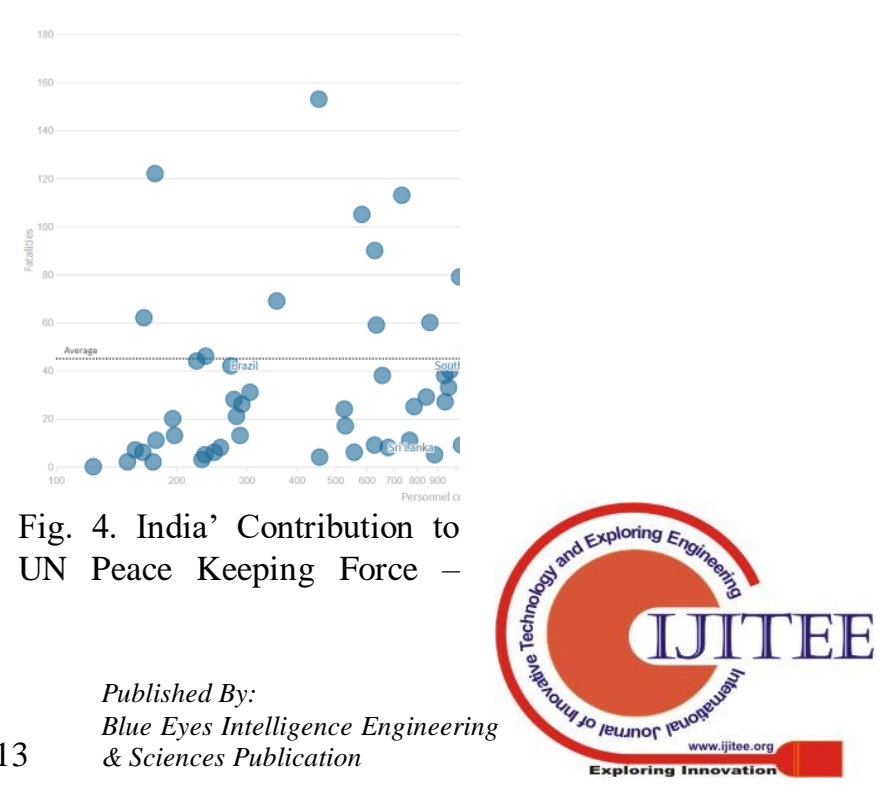


Fatalaties vs. Personnel Contributed. (Source: https://public.flourish.studio/visualisation/195747/?utm_sou rce=showcase\&utm_campaign=visualisation/195747)

The report suggests such a non-alignment policy prescription for India. To achieve these goals, 'rising' or 'contrary', India needs no ally. It requires 'partner' -a global actor who thinks alike; who plays its role by the power of its democratic and civilisational example; who possesses the potential and wherewithal to assist India to redeem its promise of lifting millions of its population from grinding poverty and allied human insecurities; who equally share its aspiration of creating a new and alternative universality; who has the conviction to stand with it for the highest human and universal values, ideals and principles (VIPs) and who has already redefined power and what to do with it.

\section{NATURAL PARTNERS}

In this regard, it may be maintained that the EU remains the perfect and reliable partner available for India to achieve its foreign and strategic policy goals, as suggested in the report. India cannot accomplish everything on its own. Partnership with the EU, which is also interested and has developed expertise in this historic task, will prove to be of great help to India. Like India, the Union too tries to lead and influence the international politics by its example and intends to replicate its success at the global level. Europein the past more than sixty years developed a genuinely different perspective on the role of power in international relations, a perspective that springs directly from its unique historical experience since the end of World War II. The modern European strategic culture represents a conscious rejection of their own past, a rejection of the evils of machtpolitik. The Union remains a sui generis or unique global actor and is projected as a civilian power (François Duchane), soft power (Joseph S. Nye) and a normative power (Ian Manners) and a post-modern power (Robert Cooper) in international politics, all at once [12]. As a civilian and soft power, the EU has discarded the option of the use of military force in international politics and to use its economic strength as an instrument of attracting and influencing the third countries and as such has become a post-modern power. Again, as a normative power, the Union is engaged in formulating and fixing international norms for itself and others to follow and to fall in line with.

\begin{tabular}{|c|c|c|c|c|c|c|c|c|}
\hline Year & 1950 & 1973 & 1981 & 1986 & 1995 & 2004 & 2007 & 20 \\
\hline $\begin{array}{c}\text { No. } \\
\text { of } \\
\text { Mem } \\
\text { bers }\end{array}$ & 6 & 9 & 10 & 12 & 15 & 25 & 27 & 28 \\
\hline
\end{tabular}

Table 2. Expansion of the EU.

Besides, the EU is also avotary of 'multilateralism' and it stands for the UN, and insists on the need for international laws, agreements, rules and institutions, which can implement and police them. The EU sincerely believes that breaches of universally accepted norms must not be allowed to go unpunished and governance schemes have to be gradually freed from the recurring veto-paralysis (at the UNSC level)that made them largely ineffective throughout the Cold War era. The EU's primary goal is to promote global and regional governance and 'effective multilateralism'. It sincerely believes that multilateralism must capacitate the international community to deal with major global and regional issues confidently and with conviction. Effective multilateralism is a system designed to enable the states that form the international community to act in unison in confronting challenges, tackling problems and resolving conflicts. It should not become an instrument aiming at mutual containment and resulting in inaction and paralysis.

To the EU, effective multilateralism implies that military power can be used under certain circumstances, to deal with challenges to international peace and security, that too as the last resortand only under authorization by the UN. To that end, the Union seeks to cooperate with regional organizations, great powers like the US and emerging powers like India. According to Álvaro de Vasconcelos, Democracy, traditional leadership of the non-aligned movement, the enduring influence of Gandhi's non-violent tradition, and the popularity of human security doctrines, which are the hallmarks of India, are more compatible with the EU's multilateral perspective [13].

Bretherton and Vogler point out that lack of overall strategic direction, which remained an impediment to the EU actorness earlier, is remedied by the announcement of the European Security Strategy (ESS) of 2003, which provides an assessment of global challenges and key threats. Three 'strategic objectives' addressing key threats, promoting security in the Union's 'neighbourhood' and supporting 'an international order based on effective multilateralismare identified by Javier Solana, the then High Representative of Foreign and Security Policy, thus marking a clear cut direction for the EU to follow [14]. To face the threats squarely, Solana advocated two strategies: "We need to pursue our objectives both through multilateral cooperation in international organisations and through partnerships with key actors (Poles of the prospective multipolar world) and to develop strategic partnerships with the US, Russia, Japan, China, Canada and India" [15]. It is significant to note that India formed part of EU's global security strategy and is being considered as one among the 'key' strategic partners.

The ESS identified UN Charter as the "fundamental framework" for international relations and prioritized its strengthening [16]. Under the framework of European Security and Defence Policy (ESDP), the Union has developed operational capacity to use outside the Union on peacekeeping and conflict prevention missions in accordance with the principles of the UN Charter. In short, the European effort was to embed their efforts in overall multilateral strategies, ideally to be led by the $\mathrm{UN}$, since they sincerely believe that all the challenges 
faced by the present day world require action to be decided in multilateral forums. As such, "effective Multilateralism" has become the EU's trademark. The EU is fully committed to maintaining and developing international law and the UN system and to any action by the international community in response to the global challenges. This is why the Europeans want to maintain the lead role of the UN in the fight against global warming. In short, the European scholars like de Vasconcelos believe that their foreign policy can only be successful if it contributes to the 'multilateralisation of multipolarity' and forges strategic partnerships with regions or countries that the EU identifies as the most suited to deal with current global problems like humanizing globalisation so that it may be beneficial to everyone [17]. When it comes to world peace, as it is stressed in the ESS, the EU aspires "international organisations, regimes and treaties to be effective in confronting threats to international peace and security, and must therefore be ready to act when their rules are broken" [18].

The Europeans emphasize on the need to ensure that the United Nations and the other institutions of global governance can operate as effectively as possible and on multilateral cooperation. Chris Patten, former European Commissioner in charge of External Relations, maintains: "The main role of the EU in international affairs must be to give teeth and bite to this multilateralism" [19]. The Union's aim to develop 'well functioning international institutions and a rule-based international order' has indeed reflected in the EU's active role in promoting international organizations and treaties [20].

\section{RESULTS AND DISCUSSIONS}

The United Nations despite being in existence for over seven decades has not seen any major democratization of it most crucial body, the Security Council. It has seen an enlargement of the non-permanent members from six to ten in 1965 but the number of permanent members remains unchanged since its inception. There has been clamour for an expansion with legitimate demand for representation reflecting global reality. India has been lobbying for the position as well. Below are some of the findings of this paper:

1. Despite the immediate need for reform of the UN setup, the attitude of the permanent members and those challenging the permanent member hopeful are a barrier to such evoultion.

2. Democratization of the UN by expanding the permanent membership does not automatically result in democratization of the UN system and decision making process.

3. India's demographic and economic size alone don't not make it a viable candidate for the position. There is also a need for India to play a global role in setting norms.

4. EU is a natural partner for India to achieve its foreign and strategic policy goals. Both parties are upholders of global norms and lead by example. EU considers India as a key strategic partner; this should further facilitate cooperation between the two in shaping global orders in a multilateral and democratic manner.

5. India must set appropriate goals as to how it hopes to use its power if it acquires permanent membership at the UNSC.

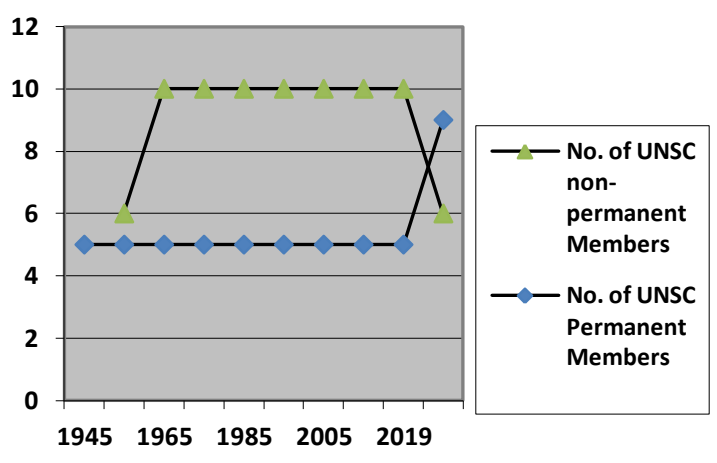

Fig. 5. What an Expansion of the UNSC Membership post-reform would look like.

\section{CONCLUSION}

India has always donned the cap of a rebel against the international norms like the NPT set by others. Now it should join hands with the EU to formulate and finalise new laws and norms, thereby becoming a norm setter on its own right rather than the breaker or challenger of established norms set by others. Such a step may bring in a sea change in the role that it has always played. India should go for positive actions instead of negative reactions to international developments. Establishing global governance to foster international cooperation, to elaborate consensual global norms and to formulate predictable, universally applicable rules to the benefit of all should be the high priority of both the powers and only in such an environment both India and the EU can thrive.

India should not only work for democratization of the UN but also towards the democratization of the way in which the UN system, especially the UNSC, works and the decisions are taken. It means that the issue is not only India getting UNSC permanent membership with veto power, but also the way in which and issues for which India is going to use its veto power and how far it is going to be different from the way in which the $\mathrm{P}$ 5 have used the veto so far.

Then, the EU should endorse and whole-heartedly support the Indian claim of UNSC membership so as to enable it to play its due role in multilateral politics. Eventually, both should use their veto power conjointly and work in concertwithin the highest and most powerful body in international politics for peace and a new world order. Only when it is allowed to take its decisions democratically, the UN will be able to prove the words of Dag Hammarskjöld that "United Nations was not created to take mankind to heaven, but to save humanity from hell" correct. If UN succeeds, whole world wins and if it fails, it is going to be the loss of entire humanity. India and EU should work hand in hand for the success of the UN. 


\section{REFERENCES}

1. Shashi Tharoor, PaxIndica. India and the World of the 21 st Century, Penguin Books India, New Delhi, 2012, pp. 366-7.

2. B.Krishnamurthy, "India and the European Union: Common Quest for Multilateralism and a Multipolar World Order", in Rajendra Jain (ed.), India and the European Union in a Changing World, Aakar Books, Delhi, 2014, pp. 18-39.

3. Jean-Luc Racine, "Pakistan and the 'India Syndrome': Between Kashmir and the Nuclear Predicament", in Christophe Jaffrelot (ed.), Pakistan. Nationalism without a Nation?,Zed Books Ltd., New Delhi, 2004, pp. 195-227, at p. 217.

4. Jan Wouters, The EU as a Multilateral Security Actor After Lisbon: Constitutional And Institutional Aspects, Louven Centre, Working Paper 80, 2012, p. 5 .

5. ShairiMathur, "Voting for the Veto:India in a Reformed UN", September 2005, The Foreign Policy Centre, London, 2005, p. 22, available at www.fpc.org.uk/publications.

6. Sunil Khilnani, "India as a Bridging Power", Prasenjit K. Basu et al, India as a New Global Leader, The Foreign Policy Centre, London, 2005, p. 8.

7. David M. Malone, Does the Elephant Dance? Contemporary Indian Foreign Policy, Oxford University Press, Oxford, 2011, p. 252.

8. Angela Stephens, Public Opinion in India and America, March 1, 2006 Avaialbe:

http://www.worldpublicopinion.org/pipa/articles/brasiapacificra/176.ph $\mathrm{p} ? \mathrm{lb}=$ bras \&pnt $=176 \&$ nid $=\& \mathrm{id}=$

9. ChinmayaR.Gharekhan, "India and the United Nations", in Atish Sinha and MadhupMohta (eds.), Indian Foreign Policy: Challenges and Opportunities, Foreign Service Institute/Academic Foundation, New Delhi, 2007, p. 200.

10. Tharoor, n. 1, pp. 419, 427.

11. Sunil Khilnani et al.,Nonalignment 2.0. A Foreign and Strategic Policy for India in the TwentyFirst Century, Centre for Policy Research, New Delhi, 2012, pp. 7-8, 69-70.

12. B.Krishnamurthy and S.Jeeva,"European Union as a Global Actor: In Perception and Action", in Jayaraj Amin (ed.), European Union in Changing International Order, Kaveri Books, New Delhi, 2013, pp.332.

13. Álvaro de Vasconcelos, 'Multilateralising' multipolarity, in Giovanni and Alvaro de Vasconcelos (eds.), Partnerships for Effective Multilateralism - EU Relations with Brazil, China, India and Russia, Chaillot Paper, No. 109, May 2008.

14. Charlotte Bretherton and John Vogler, The European Union as a Global Actor, Routledge, London, 2006, Second Edition,p.218.

15. Secure Europe in a Better World", European Security Strategy (Brussels, December 12, 2003). Available: www.consilium.europa.eu/uedocs/cmsUpload/78367.pdf

16. Desmond Dinan, Ever Closer Union-An Introduction to European Integration, Palgrave Macmillan, 2005, p. 604.

17. Vasconcelos, n. 8 , p. 30.

18. Ibid., pp. 25-6.

19. "Developing Europe's External Policy in the Age of Globalization" (Speech by Chris Patten, the then European Commissioner for External Relations on April 4, 2002). Available: http://europe.eu.int/comm/external_relationss/nfewss/patten/sp02_134. htm (14-06-02)

20. Stephan Keukeleire and Jennifer MacNaughtan,The Foreign Policy of the European Union, Palgrave, Macmillan, London and New York, 2008 , p. 59.

\section{AUTHORS PROFILE}

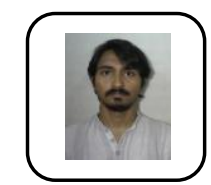

relations.

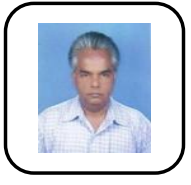
European Union, particularly in European Integration, Indo-French Relations and Human Rights. He has a teaching experience of over two decades and has guided several M.Phil. and PhD scholars. 